\title{
Solitary angiokeratoma of the tongue treated with diode laser
}

\author{
Sertan Ergun • Özgür Mete • Semen Yeșil • \\ Hakký Tanyeri
}

Published online: 28 March 2008

(C) Springer-Verlag London Ltd 2008

\section{Erratum to: Lasers Med Sci}

\section{DOI 10.1007/s10103-007-0525-Z}

In the legend of Fig. 3 and in the sentence in which this figure is cited in the text, "papillary dermis" should read "subepithelial area".

The online version of the original article can be found at http://dx.doi.org/10.1007/s10103-007-0525-z.

S. Ergun $(\bowtie) \cdot H$. Tanyeri Department of Oral Medicine and Surgery, Faculty of Dentistry, Istanbul University, Capa, 34390 Istanbul, Turkey

e-mail: sertanergun@gmail.com

Ö. Mete $\cdot$ S. Yeșil

Department of Pathology, Faculty of Medicine,

Istanbul University, Istanbul, Turkey 